\title{
A Study on the Teachers' Perceptions of Error Correction
}

\author{
Sang-soo Kim1)
}

\begin{abstract}
The purpose of this study is to examine teachers' perceptions of errors in the process of foreigners learning Korean. We use terms such as learner error and inter language for the learner's language, but there is a difference between the researcher and the teacher. How to view the learner 's language and judge the error phenomenon is a problem to be solved by researchers and teachers. In this paper, we surveyed the teachers' perception about how to understand and handle the error phenomenon that appears to Korean language learners. The data required for this study were collected through a report and analyzed using Nvivo 11. As a result of analysis, I was able to confirm what kind of learner language, error identification, error description, error explanation, when to correct errors, problems after error correction, and what to consider in error correction. Based on the results of this study, it is expected that there will be continuous discussions on teacher education, error phenomenon of learner language, and language development.
\end{abstract}

Keywords : Korean Class, Qualitative Research, Nvivo, Teacher's Perception, Error Analysis

\section{Introduction}

Error refers to incomplete language use caused by language learner's transitional language ability. Corder argued that error should be regarded as a deviation of a learner caused by a lack of knowledge of precise rules and that it should be used differently from mistake[1]. Brown also defined errors as reflecting the intermediate language abilities of learners deviated from the adult grammar of native speakers[2]. Nunan explained the error as somewhat different, rather than a mistake, by treating it as partially correct and incomplete utterances rather than deviations from standard grammatical norms[3]. Although there are many different views on errors, most scholars view errors as natural phenomena in the learner's language process, rather than as negative ones[4].

In the 2000s, Korean language education pursued qualitative growth in education and research. This is because of the diversity and specificity of Korean language education demand, it has reduced the necessity of qualitative growth in all aspects of Korean language education

Received(January 23, 2019), Review Result(1st: February 12, 2019, 2nd: March 21, 2019), Accepted(June 10, 2019)

1) (Assistant Professor) 48520 School of Free Majors, Tongmyong Univ., Sinseonro 428, Nam-gu, Busan, Korea email: kospora@naver.com 
including researchers and Korean language teachers' supply and demand, and so on.

Johansson analyzed learner errors and found that learner 's target language ability can be gauged, and learner' s ability to identify and analyze learning problems by level can be corrected to improve linguistic abilities. In error analysis, not all errors are caused by the interference of the mother tongue, but are regarded as a natural and important part of the learning process[5].

Corder argued that a learner's error presents a momentary linguistic system that the learner is learning and using[6]. This assertion tells the teacher what part of the learner needs to learn more. The learner shows the learner's learning strategy and learning process, while the learner himself/herself verifies that the hypothesis he or she has established is appropriate it is said to be a means to see. Brown defined mistakes as being due to forced guessing or accidental mistakes in the language performance process, but is capable of correcting errors, while error is a fault in the process of speech due to lack of language skills[7]. On the other hand, Diller argued that error analysis is more applicable than comparative analysis, and is necessary to solve the limitations of the control analysis[8].

However, on the other hand, we pointed out that the analytical result may be different because the analyst may differ in the objective aspect when judging the error. Also, because of the effective teaching method, it is said that the error frequency is low in difficult phrases, but high error frequency may appear in easy phrases. And it is pointed out that it is a problem of error analysis to pay attention to errors too much.

In 2000, the introduction of communication-based teaching method in foreign language education, and the change from teacher-centered education to learner-centered education. Korean language education has also changed the teaching methods and contents in order to improve learner's communication ability and felt the necessity of qualitative growth centered on learners.

In order to realize learner-centered education, Lee said that learner error study should be a starting point[9]. In other words, it is teacher-centered and researcher-centered education that determines the curriculum and contents of education without basic research on what is difficult and what is wrong. It is also necessary to study what the learners think hard and what is wrong and what they are, and make them the basis of teaching contents.

The study of error analysis of Korean language learners started in $\operatorname{Im}(1984)[10]$. In the mid-2000s, it was activated from the formation of a large corpus. In the past, based on the needs of researchers, it was based on small-scale language data, but since the mid-2000s, large-scale corpus data made it possible to produce more objective research results than before.

However, error analysis can be objectively different from analyzer when judging error[11]. 
And there is a problem that the analysis result may be changed. Also, due to differences in teaching methods, the error frequency may be low in difficult phrases, while the error frequency may be high in easy phrases[12][13]. In other words, it can be more important not only how large the data is collected and the amount of the data is small, but also how the researchers analyze the error with some criteria. As shown in the following [Table 1], the judgment of error or non-error in the same sentence may be different[14].

[Table 1] Error or Non-error

\begin{tabular}{|c|c|c|l|}
\hline $\mathrm{N}$ & $\begin{array}{c}\text { Error } \\
\text { (persons) }\end{array}$ & $\begin{array}{c}\text { Non-error } \\
\text { (persons) }\end{array}$ & \multicolumn{1}{c|}{ Example } \\
\hline 1 & 20 & 0 & $\begin{array}{l}\text { 공원에 가면 시원( } \rightarrow \text { 시원한) 바람이 있습니다. } \\
\text { A cool breeze blows in the park. }\end{array}$ \\
\hline 2 & 12 & 8 & $\begin{array}{l}\text {.....생김새 틀린( } \rightarrow \text { 다른) 사람과 사는 것은 쉬운 일이 아니다. } \\
\text { It is not easy to live with someone who is different in appearance } \\
\text { from me. }\end{array}$ \\
\hline 3 & 10 & 10 & $\begin{array}{l}\text { 그런데 이 좋은 분위기가 빨리( } \rightarrow \text { 갑자기) 변했습니다. } \\
\text { But this good atmosphere suddenly changed. }\end{array}$ \\
\hline 4 & 3 & 17 & $\begin{array}{l}\text { 이 집에서 제( } \rightarrow \text { 우리/저희) 집까지 자동차로 이분만 걸립니다. } \\
\text { It takes two minutes from here to my house. }\end{array}$ \\
\hline 5 & 2 & 18 & $\begin{array}{l}\ldots . . . \text { 가족과 채팅도 할 수 있습니다. 뿐만( } \rightarrow \text { 그분만) 아니라 인터넷으로 } \\
\text { 많은 정보를 얻을 수 있습니다. } \\
\text {......you can chat with your family. In addition to that, you can get } \\
\text { a lot of information on the internet. }\end{array}$ \\
\hline
\end{tabular}

Previous research has focused on observing and identifying errors in Korean language learners and preparing educational plans. However, little research has been done on the process of Korean language teachers recognizing and understanding learner errors before observing and identifying errors in Korean language learner. Therefore, this study aims to focus on how Korean language teachers perceive errors of Korean language learners. This will help to understand the error patterns of the learner language frequently encountered in the Korean language education and to prepare an effective education plan. The research questions for this are as follows.

1. What concepts do teachers have about errors in the learner's language?

2. What do the teachers think about the process of handling errors in the learner's language? 


\section{Methods}

\subsection{Participants}

The data collected for this study is based on a report on learner language errors written by 20 preliminary Korean language teachers. They major in Korean language education at the graduate school, and after they major, they will get the certificate of Korean language teacher and go to the education field. Therefore, they were participating in the class as a preliminary Korean language teacher.

All of them took graduate class related to 'Korean Error Analysis Research' in the 1st or 2nd semesters of 2017. Before taking the lecture, we examined what I thought about the errors in the learner's language. A total of 35 participants were enrolled. A total of 20 participants were participated in the study. The gender of the participants were four male and sixteen female. There were 15 master's degree and 5 doctoral degree.

[Table 2] Participants

\begin{tabular}{|c|l|}
\hline Gender & $\begin{array}{l}\text { Male }-4 \\
\text { Female }-16 \\
\text { Total }-20\end{array}$ \\
\hline Academic ability & $\begin{array}{l}\text { Master's course - 15 } \\
\text { Doctoral course - 5 }\end{array}$ \\
\hline
\end{tabular}

\subsection{Instrument}

In this study, we tried to analyze the data using Nvivo version 11, which is a qualitative research program, and tried to approach the case study to interpret the collected report. Nvivo is optimized for qualitative research among current programs and is the best tool for organizing unconventional data and establishing frequency and model of data[15]. 


\section{Results}

As a result of analyzing the recognition report of the preliminary Korean language teachers about the error phenomenon appearing to learners, it appeared as [Table 3]. The analysis results are classified into four categories: 'concept of error', 'error correction', 'after error correction', and 'other'.

The 'learner language' includes what is the error, the difference between error and mistake, the inter language, and grammaticality. In 'error analysis', the reason and method of error correction, the timing of error correction, and the subject of error correction are reported. In addition, 'error correction', it was reported that improvement of teaching method and confirmation of error correction after error correction should be done. In 'others', it is necessary to consider the errors to be corrected.

[Table 3] Coding Item

\begin{tabular}{|c|c|c|}
\hline Types & Contents & Node \\
\hline learner language & $\begin{array}{l}\text { error identification } \\
\text { error vs mistake } \\
\text { inter language } \\
\text { grammaticality } \\
\text { acceptability }\end{array}$ & 22 \\
\hline error analysis & $\begin{array}{l}\text { reason for error correction } \\
\text { who makes the error correction } \\
\text { target of error correction } \\
\text { the timing of error correction } \\
\text { how to correct errors } \\
\text { error identification }\end{array}$ & 80 \\
\hline error correction & $\begin{array}{l}\text { feedback } \\
\text { improvement of teaching method } \\
\text { confirmation of error correction }\end{array}$ & 14 \\
\hline others & recognition of errors etc. & 12 \\
\hline & Total & 128 \\
\hline
\end{tabular}




\subsection{Learner Language}

The following is a look at how preliminary Korean language teachers think about errors. The preliminary Korean language teachers who participated in the research basically recognized the concept of 'error' as being in contrast to 'mistake'.

- It is an error if you do not know that you are wrong or you can not correct it. It is not a mistake that the learner has not learned yet. But I do not know if it is part of the learning.[Participant 2]

- Learner's error is a phenomenon that can occur due to the interference of mother tongue in learning Korean language. Errors are distinguished from mistakes, which can be used as information that can be used to identify learners' learning situations or steps. Error is a phenomenon that appears as a process.[Participant 5]

- Errors are distinguished from mistakes. Mistakes can be corrected by the learners themselves and are not frequent. On the other hand, the error is more frequent than mistakes, because the learners do not know what is wrong and can not correct themselves.[Participant 11]

\subsection{Error Analysis}

Preliminary Korean language teachers were aware of various reasons for the necessity of error correction, the timing of error correction, the method of error correction, and the subject of error correction. They explained that error corrections can be made between teachers and fellow learners and can be corrected immediately after the error or corrected after class.

- If the error correction is not made in time, the learner will keep the rules of the target language in incomplete state. And, it goes out of the rules of the target language and continues to make improper utterances.[Participant 4]

- There is an immediate correction when an error occurs during learning and a correction after the class is over. An effective method would be better to 
remember immediately while learning, but depending on the type of learner, it http://dx.doi.org/10.21742/apjcri.2019.06.01 may be better to revise it after the lesson is finished.[Participant 7]

- In the dialogue between the learner and the teacher, there is a way of correcting or asking again when the learner's utterance has an error. And if you use a vocabulary that deviates from the level of the learner, you can present the vocabulary to that level. There are also ways to help learners using their native language.[Participant 13]

- The person who corrects the error may be a teacher, or it may correct the error by feedback from the peer learners.[Participant 14]

\subsection{Error Correction}

After correcting the errors, the preliminary Korean language teachers were thinking about what teachers should do. They explained that after the error correction, they must check to see if the error has really been corrected. And the teacher should try a variety of methods to prevent errors from appearing again.

- After the error correction, the learner can repeat the assignment or give the assignment so as not to forget the correction.[Participant 6]

- Let the learner use the contents of error correction. In order to do this, the teacher should suggest various ways such as inducing the learner to internalize the rewriting of his or her writing.[Participant 17]

After correcting the error, it is necessary to check whether the learner has reduced the error frequency during communication or writing.[Participant 20]

An assessment of the learner's error correction should be performed. You should look back at the curriculum through error correction and make sure that error correction has a positive impact on both teachers and learners.[Participant 18] 


\subsection{Others}

Preliminary Korean language teachers suggested what to consider to correct errors in the learner 's language. They explained that what is important in error correction is the teacher's attitude toward learner and learner errors.

- Since the target of error correction is the learner, it is necessary to maintain good attitude while correcting errors.[Participant 1]

- I think that the most important thing in correcting errors is learner. It is important to understand the learning ability, personality, and purpose of the learner, and to present the appropriate teaching method or various activities.[Participant 5]

- It is important that the attitude of the teacher as a natural process is not important.[Participant 10]

\section{Conclusion}

In this study, we observed how preliminary Korean language teachers think about errors in Korean language learning process. A total of 20 participants participated in the study, and they wrote and submitted a report on how to understand and accept the error phenomenon of Korean language learners. The researchers analyzed the report using Nvivo 11, resulting in a total of 128 nodes. Each node is classified into 'learner language', 'error analysis', 'error correction', and 'others'. The most discussed items were 'error analysis' and 80 out of total 128 nodes. They explained the reasons for the error correction, the method, the timing and the subjects.

The problem of handling the error phenomenon in the learner language is not simple. The same error phenomenon can be perceived differently by researchers and teachers. These differences can be reflected in the educational field and affect the learner's language development. Therefore, it is necessary to consider how the preliminary Korean language teachers' perception of errors can be applied in future education field.

In this study, we confirmed how preliminary Korean language teachers understand the 
errors that appear to Korean language learners. This will provide the necessary information for preliminary Korean language teachers and help them understand the Korean language learners they will be teaching in the future.

\section{References}

[1] S. P. Corder, The significance of learner' errors, International Review of Applied Linguistics, (1967), Vol.5, pp.161-170.

[2] H. D. Brown, Principles of Language Learning and Teaching (5th ed.), White Plains, NY : Pearson Education, (2007)

[3] D. Nunan, Designing Task for the Communicative Classroom, London : Cambridge University press, (1989)

[4] H, Song, A Study on Korean Class Analysis For Instructional Consultation, Studies of Chinese \& Korean Humanities, (2015), Vol.46, pp.97-119.

[5] D, Won, A Study on the trends of error analysis research on Korean language learner, Master's Thesis, Yonsei University of Education, (2016)

[6] S. P. Corder, Error Analysis Interlanguage, London : Oxford University, (1981)

[7] H. D. Brown, Teaching by Principles-An Interactive Approach to Language pedagogy (3rd.), London : Longman, (2008).

[8] C. M. Marianne, Teaching English as a Second or Foreign Language, Newbury House, (1999)

[9] Y, Lee, Development of Self-Analysis Methods of Teaching for the Improvement of College Education, The Journal of Yeolin Education, (2011), Vol.19, No.1, pp.1-34.

[10] S, Lee, A Research on class critique Through Korean Learner's class observation story, Korean Education, (2012), Vol.92, pp.447-470.

[11] S. Thornbury, How to teach grammar, London : Longman, (1999)

[12] D. Nunan, Second language teaching and learning, Heinle \& Heinle, (1999)

[13] S, Kim and H, Song, Understanding Korean Language Education Research, Pusan : Pusan University of foreign Studies Press, (2010)

[14] K, Ahn, Study of Korean language education, Seoul : Hankookmunwasa, (2007)

[15] J, Park, Nvivo 11 Applications : Handling Qualitative Data, Seoul : Global Contents, (2017) 